\title{
Penerapan Algoritma K-Nearest Neighbour Dalam Menentukan Pembinaan Koperasi Kabupaten Kotawaringin Timur
}

\author{
Application of K-NN Algorithm in Determining Co-operative Development \\ in East Kotawaringin Regency \\ Yuni Ambar S*1, Kusrini², Henderi ${ }^{3}$ \\ 1,2,3 Magister Teknik Informatika,Universitas AMIKOM Yogyakarta \\ E-mail: *1 ambarsetianto@gmail.com, ${ }^{2}$ kusrini@amikom.ac.id, ${ }^{3}$ henderi@gmail.com
}

\begin{abstract}
Abstrak
Saat ini pembinaan terhadap koperasi yang ada di lingkungan Pemerintah Kabupaten Kotawaringin Timur sangat diperlukan karena adanya koperasi yang baru berdiri maupun yang telah lama berdiri kinerjanya menurun yaitu omset koperasi turun sebesar 30\% dan lambat dalam melaksanakan Rapat Anggota Tahunan (RAT) yaitu pada tahun 2016 sebanyak 164 koperasi dan tahun 2017 sebanyak 140 koperasi. Dengan jumlah koperasi saat ini Dinas Koperasi kekurangan SDM pembina, oleh karena itu perlu menentukan koperasi yang diprioritaskan mendapatkan pembinaandengankriteria yaitu jenis koperasi, masa kerja, kategori, jumlah anggota, modal sendiri, volume usaha, dan SHU. Dinas Koperasi dan UKM Kabupaten Kotawaringin Timur melakukan pembinaan dengan bimbingan teknis terhadap koperasidan audit terhadap kepengurusan dan keuangan Koperasi, namun karena belum adanya pedoman dalam menentukan koperasi yang layak untuk dilakukan pembinaan sehingga sering mengakibatkan salah sasaran dalam memilih koperasi yaitu koperasi yang seharusnya mendapat pembinaan tetapi tidak dilaksanakan pembinaan.. Salah satu cara untuk mengatasi permasalah tersebut adalah dengan Data Mining dengan metode klasifikasi menggunakan algoritma K-Nearest Neighbour (K-NN). Penelitian ini menerapkan algoritma K-NN dalam menentukan koperasi yang layak mendapatkan pembina. Hasil yang dari penelitian ini adalah klasifikasi koperasi yang layak mendapatkan pembinaan dengan akurasi yang diperoleh sebesar 96,33\%.
\end{abstract}

Kata Kunci-Pembinaan, Klasifikasi, KNN

\begin{abstract}
Currently coaching of cooperatives in Kotawaringin Timur District is very necessary because the existence of cooperatives that established and have long been established, their performance has decreased, namely the turnover of cooperatives fell by $30 \%$ and slow in carrying out the RAT, namely in 2016 as many as 164 cooperatives and in 2017 there were 140 cooperatives. Cooperatives currently the Department of Cooperatives is lacking in human resources, it is therefore necessary to determine which cooperatives are prioritized to get guidance with criteria such as type of cooperative, length of service, category, number of members, own capital, business volume, and SHU. Cooperative District conducts coaching with technical guidance on cooperatives and audits of Cooperative management and finance, but due to the lack of guidelines in determining appropriate cooperatives for coaching that often results in mis-targeting in choosing cooperatives, namely cooperatives that should receive guidance but not coaching is carried out. One way to overcome these problems is by Data Mining using a classification method with K-Nearest Neighbor $(K-N N)$ algorithm. This study applies the K-NN algorithm in determining cooperatives that are eligible for guidance. The results is with an accuracy of $96.33 \%$.
\end{abstract}

Keywords - Coaching, Classification, KNN 


\section{PENDAHULUAN}

\subsection{Latar Belakang}

pengawas koperasi yangberdasarkan pada Peraturan Daerah Nomor 42 Tahun 2016 tentangSusunan Organisasi dan Rincian Tugas Pokok, Fungsi Serta Uraian Tugas Dinas Koperasi Dan Usaha Kecil Dan Menengah Kabupaten Kotawaringin Timur. Dalam peraturan tersebut Dinas Koperasi berkewajiban membina koperasi yang ada di lingkungan Pemerintah Kabupaten Kotawaringin Timur [1].

Saat ini pembinaan terhadap koperasi yang ada di lingkungan Pemerintah Kabupaten Kotawaringin Timur sangat diperlukan karena adanya koperasi yang baru berdiri maupun yang telah lama berdiri kinerjanya menurun dan lambat dalam melaksanakan Rapat Anggota Tahunan (RAT). Berdasarkan data keperasi saat ini dari 317 koperasi, yang belum melaksanakan RAT untuk tahun 2018 sebanyak 186 koperasi.

Dinas Koperasi dan UKM Kabupaten Kotawaringin Timur melakukan pembinaan yaitu dengan melaksanakan bimbingan teknis terhadap koperasi dan audit terhadap kepengurusan dan keuangan Koperasi, namun karena belum adanya pedoman dalam menentukan koperasi yang layak untuk dilakukan pembinaan sehingga sering mengakibatkan salah sasaran dalam memilih koperasi yang akan dibina hal ini ditandai dengan banyaknya koperasi yang statusnya tidak sehat yaitu berdasarkan data koperasi sebanyak 65 koperasi.

Pada saat ini Dinas Koperasi dan UKM Kabupaten Kotawaringing Timur mempunyai jumlah pegawai sebanyak 22 orang terbagi dalam 3 Bidang yaitu Sekterariat, Bidang UKM dan Bidang Koperasi, di bidang koperasi sendiri hanya terdapat 4 orang pegawai pembina. Dengan jumlah koperasi sebanyak 317 koperasi saat ini Dinas Koperasi kekurangan SDM pembina, oleh karena itu perlu menentukan koperasi yang diprioritaskan mendapatkan pembinaan. Salah satu cara untuk mengatasi permasalahan-permasalah tersebut adalah dengan menggunakan metode Data Mining.

Metode yang digunakan dalam data mining adalah klasifikasi yaitu menggunakan data keragaan koperasi yang merupakan data numerik atau nominal dengan beberapa atribut yang digunakan yaitu nama koperasi, jenis koperasi, kategori, Rapat Anggota Tahunan (RAT), masa kerja, volume usaha, modal sendiri, modal luar, Sisa Hasil Usaha (SHU). Data atribut tersebut berdasarkan data yang diperoleh dari Dinas Koperasi yang digunakan untuk penentuan layak dan tidaknya koperasi mendapatkan pembinaan.

Dalam menentukan klasifikasi menggunakan algoritma K-Nearest Neighbour (K-NN). Alasan pemilihan Algoritma KNN adalah berdasarkan data yang digunakan yaitu menggunakan data sekunder dan tujuan dari algoritma ini adalah mengklasifikasikan obyek baru berdasarkan atribut dan training sample, tidak memerlukan model algoritma seperti yang dihasilkan oleh algoritma lain, dalam klasifikasi ini berdasarkan data koperasi sebagai data pelatihan (data training).

\subsection{Tinjauan Pustaka}

Sebelumnya telah dilakukan perbandingan Algoritma KNN dan Metode Decision tree untuk mencari kedekatan antara kriteria kasus baru dengan kriteria kasus lama berdasarkan kriteria kasus yang paling mendekati. Pada penelitian tersebut menyebutkan bahwa Algoritma KNN memiliki nilai akurasi yang lebih tinggi [2]. Perbandingan antara Algoritma C4.5 dan KNN juga dilakukan untuk mendiagnosa penyakit diabetes mellitus. Hasil dari perbandingan tersebut menjelaskan bahwa algoritma KNN menghasilkan nilai akurasi yang lebih tinggi dibandingkan dengan C4.5 [3]. Penelitian lain yang bertujuan untuk mendapatkan hasil komparasi dari metode klasifikasi DC Tree-J48, K-Nearest Neighbour dan Zero-R pada kinerja Akademik. Hasil dari komparasi yang telah diimplementasikan bahwa algoritma K-Nearet Neighbour lebih baik dengan nilai akurasi tertinggi sebesar $89,04 \%$ [4]. 
Penelitian yang dilakukan peneliti dengan kesimpulan dari penelitian yang dilakukan adalah K-Means mempunyai kemampuan mengelompokkan data dalam jumlah yang cukup besar dengan waktu komputasi yang relatif cepat dan efisien. Pada penelitian menggunakan metode clustering ini terdapat kelemahan dalam menentukan pemberian pusat awal cluster, karena hasilnya nanti sangat tergantung pada pusat awal cluster tersebut [5].

Pemilihan tempat tinggal yang layak sesuai dengan 7 kriteria, yaitu Keamanan, fasilitas Umum, bebas banjir, harga, air bersih, model, sejuk dan nyaman. Untuk mementukan pemilihan kelayakan tempat tinggal digunakan metode Naive Bayes dan menggunakan pemodelan Data mining yang menghasilkan 3 kriteria utama yaitu keamanan, bebas banjir dan harga tempat tinggal [6]. Dengan menggunakan metode klasifikasi dengan algoritma C4.5untuk membentuk pohon keputusan yang menjadi alat dalam mendukung keputusan untuk memprediksi prestasi akademik mahasiswa [7]. Pada penelitian lain yang bertujuan untuk mengelompokan data kriteria penderita Thalassaemia berdasarkan umur, $\mathrm{Hb}$ level dan kebutuhan jumlah darah dengan pendekatan data mining menggunakan algoritma K-means [8].

Penelitian yang menggunakan algoritma Eclat membahas aturan asosiasi pada data transaksi suku cadang bengkel ahass. Penelitian ini menghasilkan pola transaksi konsumen untuk mengetahui informasi produk dan jasa apa saja yang sering muncul [9]. Penelitian selanjutnya yang bertujuan untuk menetapkan faktor-faktor yang menghambat proses pembinaan koperasi, metode yang digunakan adalah dengan menggunakan pendekatan yuridif empiris yang sifatnya deskriptif [10].

Untuk menentukan pola pembelian konsumen telah dilakukan penelitian menggunakan algoritma FP-Grwoth. Sehingga dengan adanya hasil dapat membantu pengelola untuk membuat keputusan yang bersifat manajerial [11]. Penelitian selanjutnya dilakukan untuk melihat pengaruh pada penentuan klasifikasi dari kinerja akademik. Kriteria yang ditentukan adalah IPK dan jenis kelamin. Penentuan Klasifikasi menggunakan algoritma NBC, yang bertujan untuk megevaluasi sebuah kinerja pada akademik mahasiswa di Perguruan Tinggi. Dari Hasil penelitian tersebut diperoleh akurai 92,30\% [12]. Pada penelitian yang bertujuan untuk memprediksi kesiapan siswa menghadapi ujian nasional menggunakan metode Decision tree mendapatkan hasil akurasi sebesar $99,48 \%$ [13].

\subsection{Landasan Teori}

\subsubsection{Koperasi}

Berdasarkan Undang-Undang Nomor 25 Tahun 1992 tentang perkoperasian, koperasi adalah suatu perkumpulan yang beranggotakan orang-orang atau badan-badan hukum koperasi yang memberikan kebebasan masuk dan keluar sebagai anggota, dengan bekerjasama secara kekeluargaan para anggotanya. Berdasarkan pasal 1 Undang-Undang Nomor 25 Tahun 1992 tentang perkoperasian dalam Undang - undang tersebut disampaikan bahwa koperasi merupakan Badan Usaha yang anggotakan orang seorang atau merupakan Badan Hukum dengan landasan kegiatannya berdasarkan pada prinsip-prinsip koperasi [14].

\subsubsection{Dinas Kopertis dan UKM Kabupaten Kotawaringin Timur}

Pemerintah Daerah Kabupaten Kotawaringin Timur membentuk dinas pembina dan pengawas koperasi yang berdasarkan pada Peraturan Daerah Nomor 16 Tahun 2016 tentang Pembentukan dan Susunan Dinas Koperasi dan UKM Kabupaten Kotwaringin Timur. Nantinya Dinas tersebut akan dipimpin oleh seorang Kepala Dinas yang berada dibawah dan bertanggungjawab kepada Bupati melalui Sekretaris Daerah.

\subsubsection{Data Mining}

Data Mining adalah mengekstraksi dan mengidentifikasi informasi menjadi informasi dan menjadi pengetahuan yang bermanfaat menggunakan teknik matematika, statistik, machine 
learning, dan kecerdasan buatan [15]. Data Mining merupakan salah satu tahapan dapam proses knowledge discovery in databases (KDD). Istilah data mining dan KDD sebetulnya memiliki konsep yang berbeda dalam penggunaannya sebagai proses penggalian data, namun kedua konsep tersebut saling berkaitan. Proses KDD adalah sebagai berikut:

1. Data Selection

Sebelum mulai melakukan penggalian informasi dalam KDD terlebih dahulu harus dilakukan seleksi data (data selection) dari kumpulan data operasional. Hasil seleksi data diletakkan terpisah dari data operasional, kemudian setelah dilakukan seleksi data baru dilakukan proses selanjutnya yaitu proses data mining.

2. Preprocessing atau Cleaning

Data hasil seleksi biasanya masih terdapat duplikasi data, terdapat data yang tidak konsisten (inkonsisten), proses memperkaya data dengan informasi lain pada data yang masih salah, misalnya salah dalam pengetikan atau salah cetak, hal ini disebut dengan proses enrichment.

3. Transformation

Agar data yang akan digunakan sesuai pada proses data mining maka data tersebut harus dilakukan proses transformasi dengan menggunakan proses coding. Proses coding dalam knowledge data discovery merupakan proses kreatif dan sangat tergantung pada jenis atau pola informasi yang akan dicari dalam basis data.

4. Data mining

Data Mining adalah teknik dalam mencari pola atau sebuah informasi dari data yang telah dilakukan proses transformasi. Metode yang digunakan dalam proses data mining adalah menggunakan algoritma yang sesuai dengan tujuan dan data yang digunakan dalam hal ini bergantung dari keseluruhan proses KDD.

5. Interpretation atau evaluation

Interpretation merupakan salah satu bagian dari proses KDD yang digunakan untuk menampilkan pola informasi yang merupakan hasil proses data mining, dan untuk menampilkan informasi ini perlu ditampilkan dalam tampilan yang mudah dimengerti

\subsection{4. $\quad$ K-Nearest neighbor (KNN)}

K-Nearest Neighbor (K-NN) adalah salah satu metode dimana metode ini melakukan klasifikasi berdasarkan data training atau data pembelajaran dilihat dari jarak yang paling dekat dengan objek berdasarkan nilai $\mathrm{k}$. Tujuan dari metode ini adalah mencari hasil klasifikasi berdasarkan jarak terdekat dari setiap objek. Untuk menentukan jarak tersdekat tersebut terlebih dahulu data dibagi menjadi data training dan data testing, setelah diperoleh data training dan data testing kemudian di hitung jarak masing-masing data testing (ecluidience Distance) terhadap data training. Rumus yang digunakan untuk mengitung jarak bisa dilihat pada persamaan ke-1.

$$
d\left(x_{i} x_{j}\right)=\sqrt{\sum_{r=1}^{n}\left(a_{r}\left(x_{i}\right)-a_{r}\left(x_{j}\right)\right)^{2}}
$$

Keterangan :

$\begin{array}{ll}d\left(x_{i}, x_{j}\right) & : \text { Euclidean Distance (Jarak Euclidean). } \\ x_{i}, x_{j} & : \text { record ke-m, record ke-n } \\ (\text { ar }) & : \text { data ke-r } \\ \mathrm{m}, \mathrm{n} & : 1,2,3, \ldots \mathrm{n} \\ \mathrm{n} & : \text { dimensi objek }\end{array}$




\section{METODE PENELITIAN}

Pada penelitian ini menggunakan metode pengumpulan data sebagai berikut:

1. Studi Pustaka

Merupakan metode pengumpulan data dengan cara mencari, membaca dan mengumpulkan dokumen-dokumen sebagai referensi seperti buku, artikel dan literatur yang berhubungan dengan data mining, metode klasifikasi, dan algoritma K-NN.

2. Wawancara

Metode ini dilakukan dengan cara mengajukan pertanyaan atau tanya jawab kepada bagian yang membidangi masalah pembinaan koperasi yaitu di Bidang Koperasi. Metode ini digunakan agar data yang akan didapatkan untuk penelitian tersebut memang dapat dipertanggungjawabkan.

3. Observasi

Metode ini adalah metode yang menggunakan cara mempelajari dan mengamati obyek yang diteliti secara langsung. Metode ini juga digunakan untuk mendapatkan data dan informasi yang dibutuhkan dari koperasi-koperasi yang ada di Dinas Koperasi dan UKM Kabupaten Kotawaringin Timur. Data yang diperoleh merupakan data sekunder dari Dinas Koperasi dan UKM Kabupaten Kotawaringin tahun 2017 yang terdapat di Seksi Pemberdayaan Koperasi. Metode Analisis Data yang digunakan pada penelitian ini adalah menggunakan metode penelitian kuantitatif deskriptif dengan pendekatan Analisis Data Sekunder (ADS).

\section{HASIL DAN PEMBAHASAN}

Data yang digunakan pada penelitian ini menggunakan data koperasi sebanyak 100 koperasi, data tersebut akan dibagi ke dalam data training dan data testing. Data yang digunakan untuk proses data mining dibagi menjadi Data training dan data testing dengan pembagian $70 \%$ data training dan $30 \%$ data testing. Setelah dilakukan proses pembagian data tersebut maka diperoleh 70 record data pada data training dan 30 record data pada data testing. Kemudian dilakukan pengurangan dan menghapus atribut-atribut yang tidak digunakan agar efek noise dapat dikurangi, seperti terlihat pada Tabel 1.

Tabel 1. Data koperasi yang telah dilakukan pembersihan data.

\begin{tabular}{|c|l|c|c|c|c|c|c|c|r|}
\hline No & Nama Koperasi & $\begin{array}{c}\text { Jenis } \\
\text { Koperasi }\end{array}$ & $\begin{array}{c}\text { Masa } \\
\text { Kerja }\end{array}$ & Kategori & RAT & $\begin{array}{c}\text { Jml } \\
\text { Agt }\end{array}$ & $\begin{array}{c}\text { Modal } \\
\text { Sendiri }\end{array}$ & $\begin{array}{c}\text { Volume } \\
\text { Usaha }\end{array}$ & SHU \\
\hline 1 & Azzahra & Lainnya & 18 & Sehat & Belum RAT & 29 & 9.743 .000 & 6.800 .000 & 1.224 .000 \\
\hline 2 & Adhiyaksa & KPRI & 27 & Sehat & Sudah RAT & 30 & 216.267 .500 & 5.900 .000 & 1.062 .000 \\
\hline 3 & $\begin{array}{l}\text { Angkutan Antang } \\
\text { Mukti }\end{array}$ & $\begin{array}{c}\text { Kop } \\
\text { Angkutan }\end{array}$ & 9 & Tidak Sehat & Sudah RAT & 23 & 12.750 .000 & 32.154 .000 & 5.787 .720 \\
\hline 4 & $\begin{array}{l}\text { Angkutan Darat } \\
\text { Raya }\end{array}$ & Lainnya & 16 & Tidak Sehat & Belum RAT & 30 & 8.583 .000 & 12.600 .000 & 208.333 \\
\hline 5 & $\begin{array}{l}\text { Angkutan } \\
\text { Organda } \\
\text { Parenggean }\end{array}$ & Lainnya & 17 & Sehat & Sudah RAT & 50 & 37.166 .500 & 39.650 .000 & 7.125 .000 \\
\hline 6 & $\begin{array}{l}\text { Angkutan Taksi } \\
\text { Mentaya }\end{array}$ & $\begin{array}{c}\text { Kop } \\
\text { Angkutan }\end{array}$ & 18 & Tidak Sehat & Belum RAT & 29 & 18.339 .200 & 2.406 .667 & 433.200 \\
\hline 7 & Anisa Nurul A'in & Kopkar & 8 & Sehat & Sudah RAT & 26 & 25.690 .000 & 56.300 .250 & 5.600 .250 \\
\hline 8 & Bahari & KPRI & 19 & Sehat & Belum RAT & 64 & 403.282 .814 & 200.870 .606 & 101.279 .076 \\
\hline 9 & Baruna & Kopkar & 23 & Sehat & Belum RAT & 23 & 26.800 .000 & 1.235 .000 & 222.300 \\
\hline 10 & Batang Pembelum & Kopkar & 22 & Tidak Sehat & Belum RAT & 18 & 87.563 .887 & 169.271 .000 & 19.449 .259 \\
\hline \multicolumn{7}{|c|}{ s/d } & \multicolumn{7}{|c|}{} \\
\hline 100 & Batu Bintang & Lainnya & 15 & Tidak Sehat & Belum RAT & 60 & 5.000 .000 & 9.750 .000 & 24.250 .000 \\
\hline
\end{tabular}


Selanjutnya dilakukan normalisasi yaitu dengan proses penskalaan nilai atribut dari data sehingga bisa jatuh pada range tertentu. Untuk menghitung jarak menggunakan rumus Euclideance maka langkah berikutnya adalah mengubah data kategori ke dalam numeric. Dapat dilakukan dengan mengganti data dengan angka tertentu asalkan konsisten, Misalkan untuk atribut Jenis, Kategori dan RAT nilai-nilainya diubah seperti pada Tabel 2.

Tabel 2. Tabel jenis koperasi

\begin{tabular}{|c|l|c|}
\hline No & Jenis Koperasi & Nilai \\
\hline 1 & Lainnya & 1 \\
\hline 2 & Kop Angkutan & 2 \\
\hline 3 & KOPKAR & 3 \\
\hline 4 & Kop TNI & 4 \\
\hline 5 & Kop Kepolisian & 5 \\
\hline 6 & KPRI & 6 \\
\hline 7 & KSP & 7 \\
\hline 8 & KUD & 8 \\
\hline 9 & Perikanan & 9 \\
\hline 10 & Perkebunan & 10 \\
\hline 11 & Pertambangan & 11 \\
\hline
\end{tabular}

Sedangkan untuk atribut kategori diubah menjadi nilai yaitu sehat $=1$, tidak sehat $=0$, kemudian untuk Atribut RAT diubah menjadi belum RAT $=0$, sudah RAT $=1$,

Untuk Atribut dalam range tertentu yaitu atribut Modal sendiri, volume usaha dan SHU, dilakukan menggunakan metode Min-Max yaitu metode normalisasi dengan melakukan transformasi linier terhadap data asli dengan rumus pada persamaan ke-2:

Xbaru $=((($ Xlama-Minlama $) /($ Maxlama-Minlama $)) *($ Maxbaru-Minbaru $))+$ Minbaru

Atribut M. Sendiri mempunyai range nilainya $1.000 .000 \mathrm{~s} / \mathrm{d} 2.000 .000 .000$ Milyar dengan nilai min 1.000.000 dan nilai maksimal 2.000.000.000 Milyar, akan dirubah dengan range nilai $1 \mathrm{~s} / \mathrm{d}$ 5, berarti nilai Minbaru nanti adalah 1 dan Maxbaru =5, contoh perhitungan diambilkan salah satu koperasi yaitu koperasi Azzahra, dimana diketahui M.Sendiri sebesar 9.743.000 dengan perhitungannya adalah :

Xbaru $=((9.743 .000-1.000 .000) /(2.500 .000 .000-1.000 .000) *(5-1))+1$

$=1,013$ (diambil tiga dibelakang koma).

Hal yang sama juga diterapkan pada atribut Volume Usaha dan SHU, sedangkan untuk nama koperasi diubah menjadi K1 s/d K100 hasil normalisasi dapat dilihat pada Tabel 3.

Tabel 3.Data koperasi yang telah dilakukan normalsasi

\begin{tabular}{|c|c|c|c|c|c|c|c|c|l|}
\hline NK & JK & MK & KAT & AGT & MS & ML & VOL & SHU & Status \\
\hline A1 & 6 & 27 & 1 & 30 & 1,5384 & 0,9975 & 1,0123 & 1,0002 & Tidak \\
\hline A2 & 3 & 1 & 1 & 78 & 1,0288 & 1,0625 & 0,9975 & 0,9975 & Pembinaan \\
\hline A3 & 1 & 16 & 0 & 40 & 1,0171 & 0,9975 & 1,0002 & 0,9980 & Tidak \\
\hline A4 & 2 & 9 & 0 & 23 & 1,0294 & 0,9975 & 1,0779 & 1,0120 & Tidak \\
\hline A5 & 1 & 16 & 0 & 30 & 1,0190 & 0,9975 & 1,0290 & 0,9980 & Tidak \\
\hline A6 & 1 & 17 & 0 & 50 & 1,0905 & 1,0062 & 1,0967 & 1,0153 & Tidak \\
\hline A7 & 2 & 18 & 0 & 29 & 1,0434 & 0,9975 & 1,0035 & 0,9986 & Tidak \\
\hline A8 & 3 & 8 & 1 & 26 & 1,0618 & 0,9975 & 1,1383 & 1,0115 & Tidak \\
\hline A9 & 1 & 14 & 1 & 360 & 1,0758 & 1,0600 & 1,0335 & 1,0175 & Pembinaan \\
\hline A10 & 1 & 15 & 1 & 355 & 1,1638 & 1,0013 & 1,0230 & 1,0021 & Pembinaan \\
\hline \multicolumn{8}{|c|}{ s/d } \\
\hline A100 & 6 & 23 & 1 & 90 & 1,3388 & 1,1579 & 1,2315 & 1,0396 & Tidak \\
\hline
\end{tabular}


Setelah didapatkan data koperasi yang udah dinormalisasi kemudian menentukanklasifikasi menggunakan algoritma K-NN dengan membagi 70\% Data Training dan $30 \%$ data testing, dan untuk mencari akurasi hasil klasifikasi menggunakan validasi silang (cross validation).

Cross validation merupakan uji validitas untuk model regresi yang melibatkan penggunaan data pembanding untuk memeriksa validitas dari perkiraan semula. Data yang digunakan untuk menguji validasi ini yaitu dari 100 data koperasi tersebut akan dilakukan 10 kali pengujian $(\mathrm{Q})$ menggunakan data training yang berbeda-beda, dan akan digunakan $\mathrm{K}=3, \mathrm{~K}=5$, $\mathrm{K}=7, \mathrm{~K}=9, \mathrm{~K}=11$ untuk mencari nilai $\mathrm{K}$ yang paling tinggi nilai akurasinya. Pembagian data training adalah seperti pada Tabel 4 .

Tabel 4.Pembagian Data Training

\begin{tabular}{|l|c|c|}
\hline No & $\begin{array}{c}\text { Pengujian } \\
(\mathrm{Q})\end{array}$ & $\begin{array}{c}\text { Data Testing } \\
\text { yang digunakan }\end{array}$ \\
\hline 1 & Q1 & A2 s/d A31 \\
\hline 2 & Q2 & A9 s/d A39 \\
\hline 3 & Q3 & A16 s/d A45 \\
\hline 4 & Q4 & A23 s/d A52 \\
\hline 5 & Q5 & A30 s/d A59 \\
\hline 6 & Q6 & A37 s/d A65 \\
\hline 7 & Q7 & A44 s/d A73 \\
\hline 8 & Q8 & A51 s/d A80 \\
\hline 9 & Q9 & A58 s/d A87 \\
\hline 10 & Q10 & A65 s/d A94 \\
\hline
\end{tabular}

Setelah diperoleh data yang digunakan untuk pengujian kemudian dicari klasifikasi dari masing-masing data testing melalui pengujian Q1 s/d Q10. Untuk pengujian Q1 data testing A2 s/d A31, perhitungan Algoritma K-NN dengan langkah-langkah sebagai berikut :

1. Menetapkan parameter yang digunakan atau $k$ (jumlah tetangga paling dekat).

Parameter $\mathrm{k}$ (jumlah tetangga paling dekat untuk data koperasi diatas adalah menggunakan nilai $\mathrm{k}=3 \mathrm{k}=5, \mathrm{k}=7, \mathrm{k}=9, \mathrm{k}=11$.

2. Kemudian menghitung jarak (euclidience distance) dari setiap objek terhadap data testing yang telah ditentukan. Rumus yang digunakan adalah berdasarkan persamaan (1)

Sebagai contoh perhitungan diambil data testing yang pertama yaitu data A2, dan contoh perhitungan jarak di data training dengan $\mathrm{NK}=\mathrm{A} 1$ adalah :

$$
\begin{gathered}
d=\sqrt{(6-3)^{2}+}(27-1)^{2}+(1-1)^{2}+(30-78)^{2}+(1,5383-1,0288)^{2}+ \\
(0,9975-1,0625)^{2}+(1,0123-0,9975)^{2}-(1,0002-0,9975)^{2}=54,6943
\end{gathered}
$$

Jadi jarak Ecluidian Distance yang diperoleh adalah sebesar 460,122. Hasil perhitungan jarak berdasarkan kasus AA2 setelah diurutkan dari terkecil ke terbesar adalah seperti terlihat pada Tabel 5.

Tabel 5. Hasil perhitungan jarak

\begin{tabular}{|c|c|c|c|c|c|c|c|c|c|c|c|}
\hline NO & NK & JK & MK & KAT & AGT & MS & ML & VOL & SHU & REK & Distance \\
\hline 1 & A1 & 6 & 27 & 1 & 30 & 1,5384 & 0,9975 & 1,0123 & 1,0002 & Tidak & 54,6943 \\
\hline 2 & A32 & 3 & 1 & 0 & 31 & 1,0072 & 1,0075 & 0,9975 & 0,9975 & Pembinaan & 48,7649 \\
\hline 3 & A33 & 3 & 0 & 1 & 23 & 1,0015 & 0,9975 & 0,9975 & 0,9975 & Pembinaan & 56,7716 \\
\hline 4 & A34 & 6 & 34 & 1 & 35 & 1,0120 & 1,0041 & 1,0012 & 0,9982 & Pembinaan & 54,2864 \\
\hline 5 & A35 & 3 & 4 & 0 & 164 & 3,8039 & 2,5407 & 12,3973 & 2,3278 & Pembinaan & 87,1079 \\
\hline
\end{tabular}


Citec Journal, Vol. 5, No. 3, Mei 2018 - Juli 2018

ISSN: 2460-4259

\begin{tabular}{|c|c|c|c|c|c|c|c|c|c|c|c|}
\hline NO & NK & JK & MK & KAT & AGT & MS & ML & VOL & SHU & REK & Distance \\
\hline 6 & A36 & 8 & 34 & 1 & 365 & 1,0164 & 0,9975 & 1,0056 & 0,9986 & Pembinaan & 289,2732 \\
\hline 7 & A37 & 1 & 25 & 1 & 28 & 1,2584 & 1,0280 & 1,1354 & 1,0333 & Tidak & 55,4989 \\
\hline 8 & A38 & 1 & 10 & 1 & 27 & 1,0134 & 0,9975 & 1,0078 & 0,9993 & Tidak & 52,9907 \\
\hline 9 & A39 & 1 & 15 & 1 & 30 & 1,0145 & 0,9975 & 1,0006 & 0,9981 & Tidak & 50,2196 \\
\hline 10 & A40 & 3 & 24 & 1 & 33 & 1,1271 & 1,1230 & 1,1484 & 1,0247 & Tidak & 50,5477 \\
\hline 11 & A41 & 1 & 19 & 0 & 31 & 1,0137 & 1,0006 & 1,0341 & 1,0041 & Pembinaan & 51,1665 \\
\hline \multicolumn{10}{|c|}{ s/d } \\
\hline 70 & A100 & 6 & 23 & 1 & 90 & 1,3388 & 1,1579 & 1,2315 & 1,0396 & Tidak & 25,2658 \\
\hline
\end{tabular}

Setelah diperoleh hasil perhitungan jarak untuk $\mathrm{NK}=\mathrm{A} 2$, kemudian untuk melihat hasil perhitungan jaraknya maka diurutkan objek - objek kedalam kelompok yang memiliki jarak dari terkecil ke besar seperti pada Tabel 6 .

Tabel 6. Data Hasil Perhitungan yang telah di rangking

\begin{tabular}{|c|c|c|c|c|c|c|c|c|c|c|c|}
\hline NO & NK & JK & MK & KAT & AGT & MS & ML & VOL & SHU & REK & Distance \\
\hline 1 & A84 & 1 & 5 & 1 & 76 & 1,0165 & 1,0214 & 0,9975 & 0,9975 & Pembinaan & 5,0005 \\
\hline 2 & A64 & 6 & 12 & 1 & 66 & 1,0091 & 0,9975 & 1,0014 & 0,9982 & Tidak & 16,6136 \\
\hline 3 & A73 & 1 & 3 & 1 & 96 & 1,0095 & 0,9975 & 0,9975 & 0,9975 & Pembinaan & 20,3227 \\
\hline 4 & A77 & 1 & 19 & 1 & 70 & 1,0203 & 1,1038 & 1,0838 & 1,0130 & Pembinaan & 21,4012 \\
\hline 5 & A62 & 3 & 5 & 0 & 99 & 1,0368 & 1,0413 & 0,9975 & 0,9975 & Pembinaan & 21,7256 \\
\hline 6 & A44 & 3 & 14 & 1 & 95 & 1,0502 & 1,0001 & 0,9997 & 0,9977 & Pembinaan & 22,8693 \\
\hline 7 & A93 & 1 & 5 & 1 & 57 & 1,0118 & 1,0163 & 0,9975 & 0,9975 & Pembinaan & 24,6172 \\
\hline 8 & A86 & 1 & 4 & 0 & 102 & 1,0103 & 0,9975 & 0,9975 & 0,9975 & Tidak & 25,2589 \\
\hline 9 & A100 & 6 & 23 & 1 & 90 & 1,3388 & 1,1579 & 1,2315 & 1,0396 & Tidak & 25,2658 \\
\hline 10 & A50 & 3 & 23 & 0 & 87 & 1,0482 & 0,9975 & 1,0057 & 0,9983 & Pembinaan & 26,2108 \\
\hline 11 & A53 & 6 & 28 & 1 & 71 & 2,7180 & 2,8913 & 4,0586 & 2,0573 & Pembinaan & 28,7689 \\
\hline \multicolumn{10}{|c|}{ s/d } \\
\hline 70 & A42 & 1 & 14 & 0 & 650 & 1,0378 & 1,0662 & 1,0353 & 1,0043 & Tidak & 572,2071 \\
\hline
\end{tabular}

Setelah diperoleh data hasil perhitungan yang telah diurutkan berdasarkan jarak terdekat kemudian di tentukan hasil nilai $\mathrm{K}$, yaitu untuk $\mathrm{K}=3$ (Pembinaan), $\mathrm{K}=5$ (Pembinaan), $\mathrm{K}=7$ (pembinaan) $\mathrm{K}=9$ (pembinaan) dan $\mathrm{K}=11$ (pembinaan). Perhitungan ini juga dilakukan pada data testing Q1 untuk A3 s/d A31. Selanjutnya untuk menghitung akurasi dari masing-masing Q pada masing-masing $\mathrm{K}(\mathrm{K} 3, \mathrm{~K}=5, \mathrm{~K}=7, \mathrm{~K}=9, \mathrm{~K}=11)$, Menghitung nilai akurasinya dapat dilakukan dengan menggunakan persamaan:

Misalkan untuk perhitungan Akurasi untuk $\mathrm{K}=3$ adalah :

$$
\begin{aligned}
\text { Akurasi } & =\frac{\text { Jumlah Klasifikasi benar }(A 2-A 31)}{\text { jumlah data uji }} \times 100 \% \\
= & \frac{28}{30} \times 100=96,66 \%
\end{aligned}
$$

Jadi hasil klasifikasi terhadap data testing sebanyak 30 data diperoleh tingkat keakurasian untuk nilai $K=3$ sebesar 93,33\%. Perhitungan ini juga di lakukan untuk $K=5, K=7, K=9, K=11$ seperti terlihat pada Tabel 7.

Tabel 7. Hasil perhitungan Akurasi pengujian

\begin{tabular}{|c|c|c|c|c|c|c|}
\hline Training (Q) & Data Testing & $\mathrm{K}=3$ & $\mathrm{~K}=5$ & $\mathrm{~K}=7$ & $\mathrm{~K}=9$ & $\mathrm{~K}=11$ \\
\hline Q1 & A2 s/d A31 & 93,33 & 96,67 & 96,67 & 93,33 & 96,67 \\
\hline Q2 & A9 s/d A39 & 96,67 & 96,67 & 93,33 & 96,67 & 96,67 \\
\hline Q3 & A16 s/d A45 & 96,67 & 96,67 & 96,67 & 96,67 & 96,67 \\
\hline Q4 & A23 s/d A52 & 96,67 & 93,33 & 96,67 & 96,67 & 96,67 \\
\hline
\end{tabular}




\begin{tabular}{|c|c|c|c|c|c|c|}
\hline Training (Q) & Data Testing & $\mathrm{K}=3$ & $\mathrm{~K}=5$ & $\mathrm{~K}=7$ & $\mathrm{~K}=9$ & $\mathrm{~K}=11$ \\
\hline Q5 & A30 s/d A59 & 96,67 & 96,67 & 96,67 & 96,67 & 96,67 \\
\hline Q6 & A37 s/d A65 & 93,33 & 90,00 & 96,67 & 96,67 & 93,33 \\
\hline Q7 & A44 s/d A73 & 96,67 & 93,33 & 96,67 & 93,33 & 96,67 \\
\hline Q8 & A51 s/d A80 & 96,67 & 96,67 & 96,67 & 96,67 & 93,33 \\
\hline Q9 & A58 s/d A87 & 93,33 & 96,67 & 96,67 & 96,67 & 96,67 \\
\hline Q10 & A65 s/d A94 & 93,33 & 96,67 & 96,67 & 96,67 & 96,67 \\
\hline \multicolumn{2}{|l}{ Rata } \\
\hline
\end{tabular}

Berdasarkan Tabel 7. Hasil akurasi pada masing-masing pengujian Q1 s/d Q10 di peroleh hasil bahwa nilai tertinggi yaitu pada $\mathrm{K}=7$ dengan nilai rata-rata sebesar $96,33 \%$.

\section{KESIMPULAN}

Hasil Klasifikasi dengan Perhitungan algoritma K-NN yang diterapkan terhadap data koperasi sebanyak 100 koperasi diperoleh hasil klasifikasi dengan prosentase akurasi sebesar $96,33 \%$, dengan nilai $\mathrm{K}=7$ sehingga dapat disimpulkan bahwa hasil klasifikasi ini dapat digunakan untuk merekomendasikan kepada Dinas Koperasi dan UKM Kabupaten Kotawaringin Timur dalam menentukan koperasi yang layak untuk mendapatkan pembinaan.

\section{SARAN}

1. Peneliti selanjutnya mengambil obyek dari dinas koperasi yang lain terutama dengan koperasi yang jumlahnya lebih banyak dari jumlah koperasi di Kabupaten Kotawaringin Timur sehingga dapat meningkatkan akurasi hasil klasifikasi.

2. Dengan menerapkan Algoritma lainnya terhadap data koperasi sehingga dapat diperoleh perbandingan untuk mendapatkan hasil akurasi yang paling besar.

3. Penerapan Algoritma ini dapat di implementasikan dalam sistem dan menggunakan bahasa pemrograman.

\section{DAFTAR PUSTAKA}

[1] Pemerintah Daerah Kota Waringin Timur, Lombok., 2016, Peraturan Daerah Nomor 16 Tahun 2016 tentang Pembentukan dan Susunan Perangkat Daerah Kabupaten Kotawaringin Timur, Waringin Timur, Sekretariat Daerah.

[2] Yunita, D., 2017, Perbandingan Algoritma K-Nearest Neighbor dan Decision Tree untuk menentukan resiko kredit kepemilikan mobil, Jurnal Informatika Universitas Pamulang, No. 2, Vol. 2, Hal. 103-107.

[3] Giat Karyono, 2016, Analisis Teknik Data Mining "Algoritma C4.5 dan K-Nearest Neighbor" untuk mendiagnosa Penyakit Diabetes Millitus, Seminar Nasional Teknologi Informasi, Bisnis, dan Desain 2016, STMIK - Politeknik PalComTech, 12 Mei 2016.

[4] Nurfaizah, Imron, M., Perdanawanti, L., 2017, Algoritma Decision Tree-J48 K-Nearest dan Zero-R pada Kinerja Akademik, Seminar Nasional Teknologi Informasi 2017, Denpasar, 4 Maret.

[5] Handoko, K., 2016, Penerapan Data Mining Dalam Meningkatkan Mutu Pembelajaran pada Instansi Perguruan Tinggi Menggunakan Metode K-Means Clustering (Studi Kasus di Program Studi TKJ Akademi Komunitas Solok Selatan), TEKNOSI, No. 03, Vol. 02, Hal. 31 40. 
[6] Fithri, D. L., 2016, Model Data Mining Dalam Penentuan Kelayakan Pemilihan Tempat Tinggal Menggunakan Metode Naive Bayes, Jurnal SIMETRIS, No. 2, Vol. 7, Hal. 725-730.

[7] Sabna, E., Muhardi, 2016, Penerapan Data Mining Untuk Memprediksi Prestasi Akademik Mahasiswa Berdasarkan Dosen, Motivasi, Kedisiplinan, Ekonomi, dan Hasil Belajar, Jurnal CoreIT, No. 2, Vol. 2, Hal. 41-44.

[8] Sulastri, H., Gufroni, A. I., 2017, Penerapan Data Mining Dalam Pengelompokan Penderita Thalassaemia, Jurnal TEKNOSI, No. 02, Vol. 03, Hal. 299-305

[9] Arinda, S. D., Sulastri, 2017, Implementasi Data Mining Menggunakan Algoritma Eclat, Prosiding SINTAK 2017, Semarang, 11 November 2017.

[10] Lestari, F. D., Kholil, M., 2018, Efektifitas pembinaan dan pengawasan koperasi oleh Pemerintah daerah, Jurnal Privat Law, No. 1, Vol. 6, 46-59.

[11] Maulana, A., Fajrin, A. A., 2018, Penerapan Data Mining untuk Analisis Pola Pembelian Konsumen dengan Algoritma Fpgrowth pada Data Transaksi Penjualan Spare Part Motor. Kumpulan jurnal Ilmu Komputer (KLIK), No. 01, Vol. 05, Hal. 27-36

[12] Mustafa, M. S., Ramadhan, M. R., Thenata, A. P., 2017, Implementasi Data Mining untuk Evaluasi Kinerja Akademik Mahasiswa Menggunakan Algoritma Naive Bayes Classifier, Creative Information Technology Journal (CITEC Journal), No. 2, Vol. 4, Hal. 151-162

[13] Rahma, N. Z., Setyono, A., 2018, Penerapan Algoritma C4.5 Dalam Memprediksi Kesiapan Siswa SMP IT PAPB Semarang Menghadapi Ujian Nasional, SISFOTENIKA, No 1, Vol 8, Hal. 35-46.

[14] Pemerintah Indonesia, 1992, Undang-Undang Nomor 25 Tahun 1992 tentang Perkoperasian, Sekertariat Negara, Jakarta

[15] Efraim, T,. Aronson, J. E., Liang, T. P., 2005. Decision Support System and Intelligent Systems, Penerbit Andi, Yogyakarta. 